\title{
TRIM16 Gene
}

National Cancer Institute

\section{Source}

National Cancer Institute. TRIM16 Gene. NCI Thesaurus. Code C106033.

This gene is involved in both keratinocyte differentiation and histone acetylation. 